\title{
ETIKA LINGKUNGAN DALAM KOSMOLOGI SUFISTIK MENURUT SEYEED HOSSEIN NASR
}

\author{
Suwito \\ Institut Agama Islam Negeri (IAIN) Purwokerto \\ Jl. A. Yani 40 A Purwokerto 53126 \\ Email: suwitons@iainpurwokerto.ac.id
}

\begin{abstract}
Environmental Ethics of Sufism Cosmology in View of Seyeed Hossein Nasr. Sufism has unique concepts about human life. It provides the ways and methods to find the highest conscious so that the sâlikîn (the followers of sufism) can be wiser than before in any aspects, including in facing ecological crisis issues. This article tried to explore and analyze Seyeed Hossein Nars's view on ecological ethics in sufism. Nasr's concept derived from tawhîd (unity). Macro and micro cosmos were God's theophany. The relation between Allah as The God and cosmos were like one face at the front of thousand mirrors. Allah is The One and there are many manifestations of his reflection. Therefore, the universe contains and accommodates the "aspects" of God. Hence, Nasr developed the concept of tawhîd became rim and axis theory. In this theory, there are similarities and likenesses with a'yan's Mulla Sadra and al-Ghazali views. Through bashîrah (the eyes of heart), the sâlik can be khalîfah and 'abd Allâh. Hence, damaging the cosmos also means damaging the relation with Allah.
\end{abstract}

Keywords: Seyeed Hossein Nasr; sufism; environmental ethics; tawhîd; Islam.

\begin{abstract}
Abstrak: Etika Lingkungan dalam Kosmologi Sufistik Menurut Seyeed Hossein Nasr. Sufisme memiliki konsep yang unik terkait dengan kehidupan, termasuk etika berlingkungan. Sufisme menyediakan jalan yang dapat digunakan untuk menemukan kesadaran tertinggi manusia. Dengan demikian, pelaku sufi (sâlik) dapat menjadi lebih arif bijaksana dalam kehidupannya, termasuk dalam menghadapi isu krisis lingkungan. Tulisan ini mengkaji dan menganalisis etika lingkungan sufi perspektif Seyeed Hosein Nasr. Konsep etika lingkungan Nasr diturunkan dari konsep unitas (tawhîd). Alam semesta (kosmos) merupakan teophani (pengejawantahan) Tuhan. Hubungan Tuhan dengan antara alam—yang beraneka ragam—diibaratkan seperti satu wujud wajah di hadapan seribu cermin. Allah adalah Maha Esa, hanya saja pantulannya yang banyak. Dengan demikian, alam semesta "memuat" aspek Tuhan. Nasr mengembangkan konsep tawhîd menjadi teori rim dan axis. Pada teori ini, terdapat unsur kemiripan dan kesamaan dengan konsep a'yan Mulla Sadra. Demikian juga terkait dengan peran manusia sebagai pemakmur alam, pikirannya sama al-Ghazâlî dan al-Jîlî. Manusia yang dapat menggunakan mata hati (intelek) adalah khalîfah dan sekaligus 'abd Allâh. Mereka inilah yang dapat memahami alam sebagai teophani Tuhan. Dengan demikian, merusak alam sama saja dengan "merusak” (hubungan dengan) Tuhan.
\end{abstract}

Kata kunci: Seyeed Hossein Nasr; sufi; etika lingkungan; tawhîd; Islam.

\section{Pendahuluan}

Krisis lingkungan global yang terjadi di berbagai belahan bumi disebabkan karena krisis spiritual. ${ }^{1}$ Menurut Merchant dalam

1 Seyeed Hossein Nasr, Man and Nature: The Spiritual Crisis of Modern Man, (London: George Allen and Unwin, 1978). Seyeed Hossein Nasr, "Islam and the Environmental Crisis", dalam The Islamic Quaterly. Vol. XXXIV. No. 4, 1994, h. 217234. Richard Evanoff, "Reconciling Self, Society, and Nature in Environmental Ethics". Capitalism, Nature, Socialism (16), 3. 2005. h. 107-108, Gillian Rice, "Pro-environmental Behavior in Egypt: Is there a Role for Islamic Environmental Ethics?" dalam Journal of Business Ethics, 65, 2006, h. 373-390; Crites, "A New Movement
Nurjaya, ${ }^{2}$ krisis ini mengantarkan pada pola hidup "serba materi". Dampaknya, pola pembangunan yang dikembangkan oleh pemerintah

Finds Commonality in Religious Tenets and Environment Causes", dalam http://www.edu/malamalama/2007/09/f1-ecology.htm. (Diakses pada 7 Juni 2017); Hope and James Young, "Islam and Ecology", dalam http://www.crosscurrents.org/ islamecology. htm. diakses pada 7 Juni 2017; Athur Sanionis, "Enchanted Landscape: Senuous Awareness as Mystical Practice among Sufis in North India", dalam The Australian Journal of Anthropology. Vol. 19, No. 1, 2008, h.17-26.

2 Nurjaya, "Kearifan Lokal dan Pengelolaan SDA", dalam http://www.manifesmaya. blogspot.com /2008/kearifan-lokaldan-pengelaan . html. diakses ada 7 Juni 2017. 
maupun swasta berorientasi dan mengejar target pertumbuhan (keuntungan) ekonomi. Pada gilirannya, pola ini akan mengakibatkan disorientasi dalam kehidupan.

Hal senada oleh Contanza et. al, Hamilton, dan Ozkaynak et. al, dalam Konchak and Pascual, ${ }^{3}$ dia mengatakan bahwa sistem sosial dan lingkungan memiliki hubungan yang erat dalam pembentukan "pola pikir" manusia dan pola interaksinya terhadap lingkungan. Lebih spesifik, Konchak dan Pascual mengatakan bahwa kebijakan ekonomi termasuk di dalamnya ekploitasi minyak fosil menjadi penyebab serius kerusakan lingkungan. ${ }^{4}$

Kerusakan lingkungan di Indonesia akibat kebijakan ekonomi dapat dilihat pada data Walhi 2012 bahwa perusahaan menyumbang 31,4 kerusakan, pemerintah $9 \%$ kerusakan, masyarakat $6 \%$ Kerugian negara karena pengelolaan sumber daya alam sebagaimana dilaporkan Indonesia Corruption Watch (ICW) sebesar 616,3 trilyun pada tahun $2015 .{ }^{5}$

Kerusakan lingkungan global direspon Barat

${ }^{3}$ William Konchak and Unai Pascual, "Converging Paradigm fo a Co-evalutionary Enveronmental Limit Discourse", dalam Environmental Economy and Policy Research", (Discussion Paper Series University of Cambridge), No. 14, 2005, h. 3.

${ }^{4}$ Bandingkan dengan pernyataan Gillian Rice (2006) yang mengatakan bahwa sikap terhadap lingkungan didasarkan pada nilai-nilai yang diyakini. Sekalipun penemuannya di Mesir justru paradoks dengan temuan tersebut, yang mengatakan bahwa gerakan pro-lingkungan di Mesir tidak dibentuk oleh syariat Islam, sekalipun Islam memiliki konsen terhadap polusi, kesehatan publik, manajemen sumber daya alam dan nilai-nilai (etika) lingkungan. Namun, hal tersebut hampir tidak pernah digaungkan di Mesir. Pendapat ini palarel dengan Hameed (2005) pada tulisannya yang berjudul "Egypt", dalam R. C. Foltz (Ed.), Environmentalism in the Muslim World(NY: Novan Science Publishers, 2005), h. 45-61 dan M. Izz Dien (2003) dalam tulisannya yang berjudul "Islam and Environment: Theory and Practies”, dalam R. C. Foltz (Ed.), Environmentalism, 107-120. Lihat Gillian Rice, "Pro-environmental Behavior in Egypt: Is there a Role for Islamic Environmental Ethics", dalam Journal Business Ethics. 65, 375, 387. Menurut catatan Walhi Kebijakan 5 Paket Ekonomi Pemerintah Jokowi-JK cukup mengejutkan dan memberi dampak signifikan bagi lingkungan hidup. Perampingan perijinan berdampak pada penyederhanaan analisis lingkungan di Kementerian Lingkungan hidup. Walhi, Tinjauan Lingkungan Hidup 2016 Wahana Lingkungan Hidup Indonesia: Keharusan Pembenahan Struktur untuk Perbaikan Tata Kelola, (Jakarta: Eksekutif Nasional Walhi, 2016), h. 5.

5 Indonesia Corruption Watch, "Penegakan Hukum Lemah, SDA Dikuras", di http://www.antikorupsi.org/id/content/ lemahnya-penegakan-hukum-akibatkan-korupsi-di-sektorsda jalan-terus, diakses, 3 Agustus 2017). Lihat juga Walhi, Tinjauan..., h. 4. dengan berbagai cara. Di antaranya adalah: (1) gerakan kembali kepada sisi spiritual agama serta menggali nilai-nilainya. Hal ini sebagaimana dilakukan White, Brown, Callicott sebagaimana dikatakan Tucker and Grim, ${ }^{6}$ Hollenbach, 7 Hart, ${ }^{8}$ Rose, ${ }^{9}$ Nasr, dan tokoh-lain, yang gerakan ini melahirkan tradisi keilmuan spiritual ecology, green spirituality, atau green hermiticism, (2) implementasi dan aksi cinta lingkungan yang koordinasi oleh gereja. ${ }^{10}$ Kegiatan ini terekam dalam beberapa tulisan seperti Green Sisters dan Greening Religion.

Nasr memiliki pandangan yang menarik tentang etika lingkungan dalam spiritual Islam (sufisme). Baginya, Islam sangat menaruh perhatian tentang ini. Dalam Islam, ada ada tiga pilar etika berlingkungan dalam Islam, yaitu: (1) tawhîd (unity), (2) khilâfa (trusteeship), (3) akhîrah (accountability, hereafter). Hope and Young menyitir Q.S. al-An'âm [6]:1; Q.S. al-An'âm [6]:102; Q.S.al-Isrâ' [17]:44; Q.S. al-Baqarah [2]:30; Q.S. al-A'râf [7]:56; Q.S. al-Hijr [15]:19," dan beberapa ayat lainnya, seperti larangan merusak dalam Islam dapat ditelusuri dari beberapa ayat, di antaranya Q.S. al-Baqarah [2]: 11-12, 205, Q.S.

${ }^{6}$ Mary Evelyn Tucker and John A. Grim, "Introduction: The Emerging Alliance World Religions and Ecology”, Daedalus. (130), 4, Fall, 2001, h. 2.

7 Hollenbach mendekati isu lingkungan sebagai wilayah aplikasi etika sosial. Dia mengeksplorasi bagaimana hubungan ekologi berdampak pada kebaikan manusia. Lihat dalam Hollenbach, The Common Good and Christian Ethics (New York: Cambridge, 2002); Lihat juga Cowdin, "Environmental Ethics" dalam Theological Studies. 69, 2008, h. 164-184.

${ }^{8}$ Hart mendekatinya dengan radical approach dengan menggunakan acara sakramen sebagai eksperiment untuk menemukan konsep creatiocentric. Lihat dalam Hart, Sacramental Common: Christian Ecological Ethics (Lanham, Md: Rowman \& Littlefield, 2006); Lihat juga Cowdin, "Environmental Ethics", h. 164-184.

9 Rose mengekplorasi alam, manusia, dan "kecantikan" Tuhan melalui perspektif etika teologi. Lihat Rose, For the Beauty of the Earth: Women, Sacramentality, and Justice, (New York: Paulist, 2006); ; Lihat juga Cowdin, "Environmental Ethics", h. 164-184.

${ }^{10}$ Konferensi-konferensi bertemakan ekologi yang diselenggarakan oleh gereja sejak 1972 di (Stockholm), "Conference on Environment and Development". Gereja-gereja mulai menyusun tantangan lingkungan; Tahun 1975 (Nairobi) World Council Churches (WCC) meletakdasarkan "just participatory", Tahun 1979 (Massachusetts) "Conference Faith, Science, and the Future", Tahun 1983 (Vancouver), "Conference Justice, Peace, and the Integrity of Creation", Tahun 1991 (Canberra) "Holy Spirit Renewing the Whole of Creation", dan seterusnya.

"Hope and Young, "Islam", dalam http://www. crosscurrents.org/islamecology, diakses pada 7 Juni 2017. 
al- Mâ'idah [5]: 32-33, 64; Q.S. al-Anfâl [8]: 73; Q.S. Hud [11]: 116; Q.S. al-Qashas [28]: 77, 83; Q.S. ar-Rûm [30]: 41; Q.S. az-Zumar [40]: 26; Q.S. al-Fajr [89]: 12 .

Tulisan ini akan mengeksplorasi etika lingkungan dalam sufisme perspektif Seyeed Hossein Nasr terkait tiga hal: (1) fungsi alam, (2) relasi alam dengan Tuhan, (3) posisi manusia di jagat alam raya.

\section{Sekilas tentang Hossein Nasr}

Terlahir di Teheran 7 April 1933, Seyyed Hossen Nasr dididik dari keluarga yang religius. Ayahnya, Seyyed Valiaullah Nasr adalah ulama, dokter, dan pendidik pada masa dinasti Qajar (1794-1925), ${ }^{12}$ dan pada masa Reza Shah (19191980) ayahnya menduduki jabatan setingkat menteri pendidikan.

Nasr kecil hidup dalam lingkungan tradisi Syiah yang kuat. Pendidikan dasar secara formal diperoleh di Teheran, kemudian dikirim ayahnya untuk belajar di bawah bimbingan Thabathaba'i (1892-1981) untuk mendalami kalam, filsafat, dan tasawuf. Di lembaga ini, dia mendapatkan pelajaran menghafal Alquran dan syair-syair Persia.

Pada masa kanak-kanak, dia hidup dalam tradisi Syiah yang kuat. Tradisi Barat diperolehnya saat melanjutkan studi perguruan tinggi di Amerika, tepatnya di Massachusetts Institute of Technology (MIT). Di lembaga ini dia meraih Bachelor of Science (B.Sc.) dalam bidang sejarah sain. Di MIT, di samping dia belajar dengan Bertand Russel (w. 1970) tentang filsafat Barat modern, ${ }^{13}$ dia juga belajar secara otodidak kearifan Timur seperti Budha, Kristen, dan Islam. Di bawah bimbingan George de Santillana, dia belajar Hinduisme. Santillana juga mengenalkannya dengan pikiran-pikiran Timur dalam tulisan René Guénon(1886-1951), A.K. Coomaraswamy (1877-1947), F. Schuon (1908-1998), dan Titus Burckhardt (1908-1984). ${ }^{14}$

12 “Qâjâr Dynasty.” Encyclopæedia Britannica. Encyclopædia Britannica Online. http://www.britannica.com/EBchecked/ topic/485405/Qajar-dynasty, diakses pada 29 April 2009.

13 Jane I. Smith, "Seyyed Hossein Nasr", dalam John L. Esposito, The Oxford Encyclopedia of the Modern Islamic Word (New York-Oxford: Oxford University Press, 1995), h. 230.

${ }^{14}$ William C. Chittick, "Preface", dalam Mehdi Aminravazi and Zailan Moris, The Complete Bibliography of Seyyed Hossein
Selanjutnya, di Harvard University (Amerika Serikat) dia meraih gelar Ph.D. pada tahun 1958 di bawah bimbingan H.A.R. Gibb dengan disertasi, "An Introduction to Islamic Cosmological Doctrine" yang kemudian tahun 1964 diterbitkan dengan judul yang sama. ${ }^{15}$ Edisi revisi dilakukan dan di terbitkan lagi pada tahun 1968 dengan judul "Science and Civilization in Islam". ${ }^{16}$

Dalam sejarah pemikiran, tradisi intelektual di Iran dipandang sebagai daerah yang mempresentasikan kontinyuitas perkembangan pemikiran keagamaan, khususnya filsafat dan tasawuf. Tradisi keagamaan Syiah menjadi faktor pendorong berkembangnya pemikiran keagamaan ini. ${ }^{17}$ Pemikir-pemikir besar lahir di daerah ini di saat tradisi pemikiran Islam global (Sunni) melemah. Tokoh-tokoh yang dapat disebut di sini misalnya yang dikenal dengan Mir Damad(w.1632), Mulla Sadra (w. 1571). ${ }^{18}$ Teheran dan Qum menjadi pusat studi Islam terutama pada masa akhir Bani Qajar dan Pahlevi hingga sekarang. Mirza Mehdi Asytiyani (w.1953), Sayyid Abu Hasan Qazwinî (w.1953), Kazim Assar (w.1975), Thabathabâ'î (w.1981). Baqir Sadr, Khomaini, Muthahhari (19191979), Ali Syari'ati (1933-1977), dan Hossen Nasr adalah mereka yang telah memanfaatkan atmosfir akademik di daerah ini.

Setelah kepulangannya dari Amerika, dia diangkat menjadi Guru Besar Sain dan Filsafat Islam pada Universitas Teheran. Tahun 1962-1965, dia menjadi dosen tamu di Harvard University dan memegang Agha Khan Chair untuk kajian Islam yang baru dibentuk di American University di Beirut. Empat tahun (1968-1972) menjadi dekan di Fakultas Sastra dan Seni di Universitas Teheran,

Nasr From 1958-1993, (Kuala Lumpur: TP, 1994), h. xlv.

${ }^{15}$ Abdul Hamid, "Konsep Tradisi Menurut Seyyed Hossein Nasr”, (Tesis), (Jakarta: UIN Jakarta, 2002), h. 34.

${ }^{16}$ Tim Penyusun, Ensiklopedi Islam, (Jakarta: PT Ichtiar Baru Van Hoev, Cet. Ke 4, 1999), Vol. 2, h. 80-82.

17 Kaum Sunni cenderung menolak filsafat setelah Ibn Rusyd (w.1198) kecuali logika dan metode argumentasi serta paham kosmologis yang masih dalam koridor teologi dan aliran sufi tertentu. Berbeda tradisi Syi'ah yang masih mengajarkan aliran paripatetik dan illuminasi di sekolah-sekolah Syi'ah. Nasr, Science, h. 271.

${ }^{18}$ Lihat Nasr, Intelektual Islam: Teologi, Filsafat, dan Gnosis. Terj. Suharsono dan Djamaluddin MZ (Yogyakarta: CIIS Press, 1995),77. Lihat Eha Julaiha, “Etika Lingkungan: Prespektif Tasawuf Nasr", (Tesis), (Jakarta: PPs IAIN Syarif Hidayatullah, 2002), h. 20. 
merangkap pembantu rektor pada (1970-1971). Dia diangkat sebagai konselor Arya Mehr University of Technology (Teheran), sampai ia meninggalkan Iran menjelang Revolusi Iran (1979).

Pada masa Shah Mohammad Reza Pahlevi (1919-1979), Nasr mendirikan Iran Imperial Academy of Philosophy dan menjadi presidennya (1975-1976). Bersama Muthahhari dan Syari'ati, dia mendirikan Husainiyyah Irsyad pada tahun Tahun 1973. Menjelang ditutupnya lembaga ini, Nasr hengkang dari Husainiyah Irsyad dengan dalih bahwa Islam yang dikembangkan Syari'ati di lembaga ini cenderung menampilkan Islam sebagai agama revolusi dengan menghilangkan aspek spiritual. Menjelang revolusi Iran, Nasr berada di Amerika Serikat dan memutuskan untuk tidak pulang ke negerinya. la mengajar di beberapa universitas, seperti Temple University, dan George Washington University.

Karya setelah disertasinya adalah Three Muslim Sage (1964). Buku yang diterbitkan oleh Harvard University ini menjelaskan tiga aliran penting dalam pemikiran, (1) paripatetik (masysyâiyah), (2) iluminasi isyrâqiyah, (3) gnosis (irfân). Selanjutnya, pada tahun 1966, dia menulis Ideal and Realities of Islam. ${ }^{19}$ Dalam buku ini, dia menjelaskan Islam ideal dan Islam dalam realitas sejarah yang memiliki banyak variasi.

Buku penting terkait dengan etika lingkungan adalah Man and Nature: The Spiritual Crisis of Modern Manyang terbit pada 1968. Adapun bukubuku lainnya, antara lain: Sadr al-Dîn al-Syirâzî and His Transcendent Theosophy (1970), Living Sufism (1972), Islam and the Plight of Modern Man (1975), Islamic Science: An Illustrated Study (1976), An Note Bibliography of Islamic Science (1976). Islamic Life and Thought (1981), Knowledge and the Sacred (1981), Traditional Islam in the Modern World (1987), Muhammad Man of Allah (1982), Islamic Art and Spirituality (1987), Religion and Religion, The Challenge of Living in a Multi Religious World (1991), The Need for Sacred Science (1993), The Young Muslim's Guide to the Modern World (1993), The History of Islamic Philosophy (1996). ${ }^{20}$

${ }^{19}$ Lihat Nasr, Islam dalam Cita dan Faktra. Terj. Abdul Rahman Wahid dan Hasyim Wachid, (Jakarta: Lapenas, 1981); Lihat Abdul Muhid, Konsep, h. 41.

${ }^{20}$ Lihat Eha Julaiha, “Etika Lingkungan..., 2002.

\section{Kosmologi Sufi dan Diskursus Etika Lingkungan}
1. Kosmologi Sufi: Relasi Tuhan, Manusia, dan Alam

Secara bahasa, kosmologi berasal dari kata cosmos (Yunani) ${ }^{21}$ berarti alam dan logos (Yunani) berarti ilmu. Kosmologi berarti ilmu tentang asal usul cosmos.22 Secara istilah, kosmologi adalah ilmu yang mempelajari asal-usul, evolusi, ${ }^{23}$ struktur, ${ }^{24}$ dan bentangan luas alam semesta. ${ }^{25}$

Sufisme merujuk pada aspek spiritual Islam. ${ }^{26}$ Walker menjelaskan bahwa sufisme "..."emotional" expression of Islamic practice defined by the desire to achieve a symbolic union with God through love". ${ }^{27}$ Menurut Suwito, sufisme merupakan (1) sistem etika, (2) seni/estetika, dan (3) atribut yang berbasis pada spiritual Islam. ${ }^{28}$

Ketika membahas asal-usul alam dalam diskursus Sufi, paling tidak ada empat teori besar, yakni: (1) teori iluminasi (isyrâqî), (2) teori manifestasi (tajallî), (3) teori hikmah mutha'alliyah, (4) teori atomistik al-Ghazâlî. ${ }^{29}$ Pertama, teori iluminasi (isyrâqî) dikonsepsikan oleh Suhrawardi (w.1191). Teori ini dikategorikan

${ }^{21}$ Kathleen Crowther, et. al.,"The Book Everybody Read: Vernacular Translations of Sacrobosco's Sphere in the Sixteenth Century", Journal for the History of Astronomy, Vol. 46, No. 1, Feb 2015, h. 4-28.

${ }^{22}$ Richard Yonck, "Making Waves in The Cosmos", The Futurist; Washington, Vol. 48, No, 4, Jul/Aug, 2014, h. 8-10.

${ }^{23}$ Richard Yonck, "Making Waves..., 8-10. Lihat juga Earl C.Joseph, "Where Are We ? The Multi Shelled Universe-A-Big Bang Alternative", Futurics, Vol. 31. No.3/4, 2007,h. 38-45.

${ }^{24}$ Will Clemens, "On the Big Bang Theory Success: A Casual Analysis”, Pennsylvania Literary Journal, Cochran, Vol. 5, No. 3, Fall 2013, h. 58-85,153; Kirk D.Hagen, "Eternal Progression in Multiverse: An Explorative Mormon Cosmology", Dialogue: A Journal of Mormon Thought, Vol. 39, No.2, Summer 2006,h. $1-45,178$.

${ }^{25}$ Reid Goldsborough, "How Important is Information", Tech Directions; Ann Arbor, Vol. 72, No. 4, Nov 2012, 12.Kirk D.Hagen, "Eternal Progression in Multiverse: An Explorative Mormon Cosmology", Dialogue: A Journal of Mormon Thought, Vol. 39, No.2, Summer 2006, h. 1-45,178.

${ }^{26}$ Farhat Iftikhar Gill, "Sufism and Modernity", Journal of Asian Civilizations, Vol. 36, No. 2, Dec 2013, h. 199-VI.

27 Bethany J.Walker,"Commemorating the Sacred Spaces of the Past: The Mamluks and the Umayyad Mosque at Damascus", Near Eastern Archaeology; Vol. 67, No. 1, 2009, h. 26-39

${ }^{28}$ Suwito NS, Eko-Sufisme: Konsep, Strategi, dan Dampak (Yogyakarta: Buku Litera, 2011), h. 37, Lihat Paul L. Heck, ed., Sufism and Politics: The Power of Spirituality (Princeton, NJ: Markus Wiener Publishers, 2007), see introduction by the editor, h. 1.

${ }^{29}$ Suwito NS, Eko-Sufisme..., h. 48-50. 
dalam sufisme, karena kebenaran tidak hanya diperoleh melalui rasio yang diskursif, tetapi intuitif. Teori ini mengatakan bahwa Tuhan adalah cahaya, sebagai satu-satunya realitas yang sejati. Menurut teori, alam semesta memancar dari Tuhan. Terdapat perbedaan istilah dan struktur kosmis antara iluminasi Suhrawardi dan Emanasi Ibn Sina. ${ }^{30}$ Ada dua jenis pancaran, (1) vertikal (thûlî), (2) horisontal (bumi, ardh). Pancaran vertikal memancar dari Tuhan secara vertikal melalui serangkaian cahaya dari cahaya pertama terdekat (nûr al-aqrab) hingga yang terjauh. Pancaran horizontal disebut arbâb al-ashnâm, yakni semacam prototipe bagi makhluk yang berada di alam fisik. ${ }^{31}$

Kedua, teori manifesitasi (tajallî), dikenal secara luas dengan istilah wahdat al-wujûd. ${ }^{32}$ Teori ini dinisbahkan pada Ibn `Arabî (w.1240) sebagai pencetusnya. Teori ini mengatakan bahwa wujud yang riil adalah al-Haqq (Allah). ${ }^{33}$ Selain-Nya adalah bayangan (tidak riil). ${ }^{34}$ Alam yang beraneka ragam adalah manifestasi dari entitas Wujud Yang Esa. Analogi hubungan antara alam dengan wujud digambarkan melalui "wajah" dengan "gambar" wajah dalam beberapa cermin. Wajah yang satu itu dapat terpantul melalui seribu satu cermin. Cermin "sempurna" yang dapat menggambarkan "wajah" Tuhan secara utuh adalah manusia sempurna (insân al-kâmil). ${ }^{35}$ Konsep insân al-

${ }^{30}$ Emanasi paripatetik (Ibn Sina), membagi alam semesta menjadi dua, yakni 1) langit, 2) dunia bawah bulan (bumi). Sedangkan Iluminasi Suhrawardi membadinya menjadi tiga, 1) Wilayah dunia spiritual murni (berada di atas langit), 2) wilayah langit, 3) wilayah bumi. Wilayah dunia spiritual murni disebut dengan Timur (Orient/Masyriq), sedangkan langit dan bumi disebut Barat (Occident/Maghrib).

${ }^{31}$ Sajjad HRizvi, "An Islamic Subversion of The Existenceessence Distinction? Suhrawardi's Visionary Hierarchy of Lights, Asian Philosophy Vol. 9, No. 3, Nov 1999, h. 219-227.

${ }^{32}$ Ibn 'Arabî, al-Futûhât al-Makkiyyah, 4 Jilid. (Kairo: Dâr alKutub al-`Arâbiyyah al-Kubrâ, 1329/1911. Dicetak ulang di Beirut: Dâr al-Fikr, TT), 2: 516. Kautsar Azhari Noer, Ibn 'Arabî, Wahdat al-Wujud dalam Perdebatan, (Jakarta: Paramadina, 1995), h. 34$35,36$.

33 Ibn 'Arabî, Kitâb al-Jalâlah dalam Rasâil Ibn al-Arabî, Part 2 (Heydarabad-Deccan: The Dairat al-Ma'ârif al-Osmania, 1948), h. 9; Lihat Kautsar Azhari Noer, Ibn al-Arabî..., h. 35, 145.

${ }^{34}$ Ibn 'Arabi, al-Futûhât...,h. 2: 519; Lihat Kautsar Azhari Noer, Ibn al-Arabî..., h. 35.

35 Konsep insan al-kâmil secara lengkap dibahas oleh alJîî (w.1421) Bagi al-Jîîal-insan al-kâmil merupakan akumulasi dari hakikat wujûd, baik hakikat tinggi yang halus (al-haqâiq alwujûd al-'ulyâ bi al-lathifah) maupun hakikat yang rendah dan kasar (al-haqâiq al-wujûdiyyah al-shuffliyyah bi kashâfatihî). kâmil ini diuraikan lebih jelas pada al-Jîlî (w.1421), yang secara konsepsional pernah dibahas oleh al-Ghazâlî (w.1111) hampir tiga abad sebelumnya dengan istilah yang berbeda. ${ }^{36}$ Dalam term yang lain, al-Ghazâlî menyebut al-wâshilûn dengan almutha yang didefinisikan sebagai khalîfah Allah, yakni pengganti, pengatur yang memiliki posisi paling tinggi di alam semesta. ${ }^{37}$

Ketiga, teori hikmah muta'alliyah ini dikonsepsikan oleh Shadr al-Dîn al-Shirâzî atau Mulla Shadra (w.1641) dengan menyintesiskan teori emanasi, ilmuninasi, dan manifestasi. ${ }^{38}$ Kartanegara ${ }^{39}$ menilai bahwa aliran hikmah ini mirip dengan iluminasi Suhrawardi (w.1196). Corak teori ini menyintesiskan rasio (diskursif), dan mistis (intuitif). Wujud sejati adalah bukan esensi (pemahaman tentang wujud), tetapi wujud itu sendiri. Konsep Shadra yang menarik adalah berkaitan dengan konsep wujud. Baginya, wujud mengalami transformasi. Dalam istilah Sadra dikenal dengan al-harâkah al-jawhariyyah (perubahan trans-substansial). Menurut ajaran ini, perubahan bukan hanya pada aksidental, tetapi juga substansial. ${ }^{40}$ Selama ini,telah dipahami substansi adalah fixed. Misalnya, substansi hewan itu fixed sehingga dia tidak mungkin akan berubah menjadi yang lain. Tetapi bagi Shadra, substansi tidaklah fixed, dia dapat berubah secara signifikan.

${ }^{36}$ Dalam bahasa lain, al-Ghazâlî, (w.1111 M) dalam Misykât al-Anwâr menggunakan term al-wâshîlûn untuk menunjuk personifikasi manusia yang sampai pada tingkat paripurna. Alwâshilûn menurutnya adalah orang-orang yang telah sampai pada pengenalan kepada Tuhan melalui dhawq (intuisi) yang maksimal. Menurutnya, ada dua jenjang (maqâm) al-wâsilûn ini, 1) orang yang mendapatkan pengetahuan terlepas dari indera dan pikiran, yang ada hanyalah keindahan, kesucian Tuhan dan dirinya sendiri, 2) orang yang dengan kesadarannya telah dapat menyatu dengan Tuhan. Al-Ghazali, Misykât al-Anwâr, dalam Muhammad Musthafâ Abû A'lâ (Ed.), Al-Qushûr al-Awâly, (Kairo: Maktabah Jundi, 1970), h. 48.

37 Annimarie Schimmel, Dimensi Mistik dalam Islam, (Jakarta: Pustaka Firdaus, 2000), h. 282-283.

38 Siavash Asadi, "An Interpretation of Proper Name References Based on "Principality of Existence" Theory", International Journal of Islamic Thought, Vol. 11, Jun 2017, h. 43-51.

39 Mulyadhi Kartanegara, Gerbang Kearifan, (Jakarta: Lentera Hati, 2005), h. 69.

40 Ali ArshadRiahi, Mohammad Nassrisfahani, Mehdi Jafarzadeh, "Mulla Sadra and Evolution Theory", International Journal of Islamic Thought, Vol. 8 (Dec 2015): h. 1-12; Olga Louchakova-Schwartz, "A Phenomenological Approach to Illuminationist Philosophy: Suhrawardi's Nur Mujarrad And Husserl's Reduction", Philosophy East and West, Vol. 65. No.4, Oct 2015 ,h. 1052-III. 
Perubahan pada level aksidental terjadi hanya apabila ada perubahan pada substansi. ${ }^{41}$ Dengan konsep "trans- substansial movement" ini Shadra adalah teosofis proses seperti Whitehead di Barat. ${ }^{2}$

Keempat, konsep wujûd al-Ghazâlî. Menurutnya, konsep ada (being), dalam arti tertentu disebut eksistensi-merupakan konsep dasar yang paling umum meliputi semua hal yang mawjûd (yang ada).43 Menurutnya wujûd ada empat yaitu: (1) wujûd haqiqy atau dzaty, (2) wujûd fî al-dhân, (3) wujûd fî al-lafadz, (4) wujûd fî al-kitâbah. Dua yang pertama bersifat universal, dan dua wujud berikutnya bersifat simbolis. Keempat wujud tersebut bersifat hirarkis.

Bagi al-Ghazâlî, segala sesuatu selain Allah (mâ siwâ Allâh) adalah baru dan diciptakan. Oleh karena itu, Allah adalah hakikat segala yang ada. ${ }^{44}$ Walau demikian, konsep tersebut tidak mengarah pada paham ittihâd, hulûl ataupun wahdat alwujûd tetapi wahdat al-syuhûd. Dia menolak tiga faham di atas, karena paham tersebut cenderung kearah ketuhanan yang bersifat pantheisticimanenis yang menurutnya dapat merusak tauhid yang merupakan sendi pokok agama.

\section{Diskursus Etika Lingkungan Modern}

Etika lingkungan menjadi perdebatan akademik dan ramai didiskusikan oleh para pakar pada penghujung akhir tahun 1960. Pemicunya adalah White yang menulis artikel berjudul "The Historical Roots of Our Ecological Crisis", Science. 155, 1967.45 Di mana, dia mengatakan bahwa pemicu krisis lingkungan adalah kitab suci agamaagama yang mengatakan bahwa alam diciptakan untuk manusia. Dalam konteks ini etika lingkungan

${ }^{41}$ Lihat Caner Dagli, “On Beginning a New System of Islamic Philosophy”, The Muslim World, Vol. 47, No. 1, Jan 2004, h. 1-27.

${ }_{42}$ Mulyadhi Kartanegara, Gerbang Kearifan, (Jakarta: Lentera Hati, 2005), h. 68-76, 107-108.

43 Al-Ghazâlî, Mahk al-Nazhar fî al-Mantiq, (Beirut: Dâr al-Nahdlah al-Haditsah, 1966), h. 106, al-Ghazâlî, Maqâsid alFalâsifah. Cet. ke-II (Mesir: Dâr al-Ma'ârif, TT), h. 141, 170.

${ }^{44}$ Al- Ghazâlî, Ihyâ' Ulûm al-Dîn. Juz I, (Beirut: Dâr al-Fikr, TT), h. 104-105.

${ }^{45}$ Menurut Mary Evelyn Tucker and John A. Grim, artikel White sebetulnya mengisyaratkan dimulainya usaha refleksi kontemporer terkait tentang penyusunan sikap ramah lingkungan yang dibentuk oleh pandangan agama. Namun demikian, artikel ini dikemudian hari direspon sebagai cikal bakal lahirnya antropsentris. yang muncul adalah antroposentris atau alam menjadi subordinat manusia. Manusia adalah pusatnya. Partridge juga mengatakan bahwa kesimpulan tulisan White adalah bahwa, "Nature was created for mankind's benefit, and it is role to be the master of nature". Tuhan menciptakan bumi sebagai taman dan habitat untuk manusia. ${ }^{46}$

Pendapat di atas perkuat secara rasional oleh Gunn dalam jurnal Landscape Architecture yang mengatakan, "The only reason anything is done on this earth is for people... Surely we do all our act earthly environment, but I have never heard a tree, valley, mountain or flower thank me for preserving it". Pendukung lainnya dari etika lingkungan antroposentris Shephard dan McKinley dalam buku suntingan mereka yang berjudul "The Subversive Science: Essays Toward an Ecology of Man".47 Ketiga pendapat ini kemudian dikenal dalam masyarakat ekologi sebagai pendapat antroposentris, dalam artian lingkungan atau alam untuk manusia. Sebagai sebuah paradigma, antroposentris didukung oleh pemikir kontempoter Feinberg.

Perdebatan etika lingkungan yang antroposentris selanjutnya melahirkan tumbuhkembangnya pemikiran tentang etika lingkungan. Vander Veer dalam The Environmental Ethics and Policy Book dan William Frankena yang mengusung teori tentang animal liberation. Selanjutnya, pendapat kedua tokoh ini disempurnakan oleh pejuang hak asasi hewan seperti Singer dan Regan. ${ }^{48}$ Teori Gaia-centrism theory atau dengan sebutan deep ecology theory. Peletak dasar teori ini adalah Leopold dalam bukunya $A$ Sand and County Almanac: With Essays on Conservation from Round River. Inti dari aliran mengatakan bahwa manusia adalah "untuk alam". Pendapat

${ }^{46}$ Lynn White dalam, "The Historical Roots of Our Ecological Crisis", Science. 155, 1967. Lihat juga Ernest Partidge, "Topic Environmental Ethics". www.gofly.org, diakses pada tanggal 5 Juni 2008. Lihat juga David Nir, "A Critical Examination of the Jewish Environmental Law and Bal Tashchit: Do Not Destroy". Georgetown International Environmental Law Review. (18), 2. 2006, h. 335-336.

47 Paul Shephard, "Ecology and Man - A Viewpoint", dalam Paul Shephard and Daniel McKinley (Ed.), The Subversive Science: Essays Toward an Ecology of Man, (Boston: Huougton-Mifflin, 1969).

${ }^{48}$ Suwito NS, Eko-Sufisme..., h. 31. Lihat Peter Singer, “Equality for Animal ?", Practical Ethics (Cambridge: Cambridge University Press, 1993), h. 55. 
ini didasarkan pada pemikiran bahwa manusia merupakan bagian dari makro kosmos. Pendapat ini didukung oleh Holmes Rolston dan Baird Callicott. Penyataan terkenal dalam aliran ini adalah, "Everything is connected to everything else".

Para tokoh eko-feminis seperti Maria Mies, Vandana Shiva, Mery Melor, dan Ariel Salleh adalah tokoh eco-feminist yang memiliki kedekatan dengan paradigma ekosentrisme.Namun, perbedaannya kalau eko-feminis cenderung menggunakan logika berfikir Marxian. ${ }^{49}$

Paradigma keempat adalah teori spiritual ekologi. Beberapa kali konferensi aktivis agama membahas fenomena akademik ini. Dalam perjalananya, muncul lapangan kajian baru yang dikenal dengan Spiritual Ecology atau Green Religion, dan nama-nama sejenisnya. Kajian ini dimaksudkan untuk menggali nilai-nilai agama yang ramah lingkungan. Di Barat, proses pengawinan antara isu lingkungan dengan agama (spiritual) dilakukan oleh beberapa tokoh di antaranya adalah Thomas Berry, David Kinsley, ${ }^{50}$ Lislie E. Sponsel, ${ }^{51}$ Roger Gottlieb, ${ }^{52}$ Mary Evelyn Tucker and John Grim, ${ }^{53}$ dan termasuk Nasr. ${ }^{54}$ Pendekatan ini digunakan sebagai pisau bedah dan penggunaanya disesuaikan dengan tema pembahasan yang relevan.

\section{Etika Lingkungan Nasr 1. Pandangan Nasr terhadap Alam}

Ide utama Nasr berkaitan dengan etika lingkungan (ecological ethics) berawal dari konsepnya tentang unitas (tawhîd). Baginya,

49 Ariel Salleh, "Ecofeminism as Sociology". CSN, (14), 1, 61-62; Lihat juga Maria Mies and Vandana Shiva, Ecofeminism, (London: Zed Books, 1993); juga. Mery Mellor, Feminism and Ecology (Cambrigde: Polity, 1997).

50 David Kinsley, Ecology and Religion: Ecological Spirituality in Cross-Cultural Prespective (Prentice-Hall, 1995).

51 Sponsel, "Why a Tree is more than a Tree: Reflection on the Spiritual Ecology of Sacred Tree in Thailand", dalam Sulak Sivaraksa, et. al. (Ed.), Santi Pracha Dhamma, (Bangkok: Santi Pracha Dhamma Institute, 2001), h. 364-373.

${ }^{52}$ Roger Gottlieb, A Greener Faith: Religious Environmentalism and Our Planet's Future (New York: Oxford, 2006), 215. Lihat juga Daniel Cowdin, "Environmental Ethics" dalam Theological Studies. 69, 2008. h. 164-165.

53 Mary Evelyn Tucker and John A. Grim, "Introduction: The Emerging Alliance World Religions and Ecology", Daedalus. (130), 4, Fall 2001.

54 Lihat Suwito NS, Eko-Sufisme..., h. 32. realitas (wujûd) adalah satu. Dunia nyata adalah satu dari keadaan wujud yang banyak. ${ }^{55}$ Bagi Nasr, lembaran buku dengan teksnya (yang terdiri dari huruf-huruf) dapat digunakan untuk menerangkan masalah ini. Huruf adalah simbol-simbol (tertulis) secara beragam. Walaupun demikian, simbol huruf-huruf tersebut berasal dari hakikat yang satu, yakni "realitas" yang berasal dari bunyi nafas yang keluar dari kerongkongan yang sama.

Nasr memandang antara Alquran dengan alam semesta (cosmos) memiliki kesamaan wujud. Alquran adalah wahyu yang diturunkan dengan berbagai simbol tulisan dan kata yang terhimpun (the recorded quran), sedang alam adalah wahyu dalam bentuk kosmik (takwîn). ${ }^{56}$ Alam adalah sebuah buku yang berisi wahyu. ${ }^{57}$ Dengan demikian (qur'an cosmic), keduanya adalah "kitab suci" Tuhan.

Menurut Nasr, pandangan Islam tentang lingkungan didasarkan pada Alquran. Alquran tidak hanya berbicara kepada laki-laki dan perempuan, tetapi juga kepada alam (kosmos). Isi kosmos, seperti tumbuhan, hewan, matahari, laut, mineral dijadikan Tuhan sebagai saksi keberadaan-Nya..$^{88}$

\begin{tabular}{|c|c|c|}
\hline Kriteria & $\begin{array}{l}\text { Al-Quran Kitab } \\
\text { (Tadwinî) }\end{array}$ & $\begin{array}{l}\text { Al-Quran Kosmis } \\
\text { (Takwinî) }\end{array}$ \\
\hline Wujud & $\begin{array}{l}\text { Tertulis dalam sebuah } \\
\text { buku suci }\end{array}$ & $\begin{array}{l}\text { Tertulis pada kosmos } \\
\text { (baik makro maupun } \\
\text { mikrokosmos) }\end{array}$ \\
\hline $\begin{array}{l}\text { Element } \\
\text { (ayât) }\end{array}$ & $\begin{array}{l}\text { Keanekaragaman } \\
\text { huruf ( } 29 \text { huruf } \\
\text { hijâiyyah) } \\
\text { Huruf adalah simbol- } \\
\text { simbol bunyi yang } \\
\text { berasal dari sumber } \\
\text { (nafas) yang satu }\end{array}$ & $\begin{array}{l}\text { Keanekaragaman } \\
\text { ciptaan (mawjûd). } \\
\text { Mawjûd ini adalah } \\
\text { simbol-simbol dari } \\
\text { (drama puitik) wujud } \\
\text { yang Esa. }\end{array}$ \\
\hline Pesan Utama & $\begin{array}{l}\text { Pengetahuan dan } \\
\text { Kesadaran Ketuhanan }\end{array}$ & $\begin{array}{l}\text { Pengetahuan dan } \\
\text { Kesadaran Ketuhanan }\end{array}$ \\
\hline $\begin{array}{l}\text { Cara } \\
\text { Memahami }\end{array}$ & $\begin{array}{l}\text { iqra atau menyingkap } \\
\text { symbol-simbol } \\
\text { (konten dan konteks) }\end{array}$ & $\begin{array}{l}\text { iqra atau menyingkap } \\
\text { makna simbol } \\
\text { dari drama puitik } \\
\text { serta tarian kosmik } \\
\text { (kausalitas dan } \\
\text { relasional) }\end{array}$ \\
\hline
\end{tabular}

55 Nasr, Sain..., h. 1-5. Bandingkan dengan Eha Julaiha, Etika..., h. 27-31.

${ }^{56}$ Lihat juga Kautsar Azhari Noer, "Menyemarakkan Dialog Agama”, dalam Dekonstruksi Mazhab Ciputat, (Bandung: Aman Wacana Mulia, 1999), h. 64-66.

57 Hossein Nasr, Intelegensi \& Spiritualitas Agama-agama. Terj. Suharsono dkk, (Jogjakarta: Inisiasi Press, 2004), h. 199.

${ }^{58}$ Nasr, "Islam dan Krisis Lingkungan", terj. Dalam Islamika. No.3 Januari-Maret 1994, h. 5. 
Sains modern memisahkan realitas empirik sensual dan empirik logik dengan realitas yang ada di belakang manifestasi kosmos. Nasr memandang mendesak perlunya memasukkan aspek sensibilitas yang mendorong lahirnya pengetahuan yang bukan hanya sekedar ilmiah, tetapi lahir tatanan pengetahuan yang lebih tinggi. Nasr menyebut pengetahuan ini dengan istilah pengetahuan tradisional. Tentang alam, Nasr bahkan mengharuskan penggunaan bahasa simbolis dalam sains alam (kosmologi) tradisional. Dalam konteks ini, ada beragam pembahasan alam yang muaranya sama. Berbagai istilah dapat disebut di sini seperti cosmologia perennis dan cosmic in devinis yang keduanya berbicara tentang alam (cosmos), sophos, dan metafisika (Tuhan) di balik alam. Dalam konteks ini, Ali mengatakan bahwa, Nasr "...advocates Islam's "sacralised vision of nature" asameans of warding off impending ecological disaster. ${ }^{59}$

Bagi Nasr, kosmologi tradisional mengijinkan manusia memikirkan alam sebagai hal yang sakral. Dalam bahasa Zaidi, dia mengatakan bahwa, according to the Traditionalist... wisdom of the World Religions always points to a Sacred Source as the ultimate basis of reality. ${ }^{60}$ Dengan kata lain, alam dipandang dari perspektif pengetahuan "suci" dengan menggunakan kesucian mata hati (intuisi). Proses yang demikian melahirkan pengetahuan bahwa alam adalah teofani Tuhan. ${ }^{61}$

Jika dilihat alur pikir unitas (tawhîd) Nasr, didapatkan pengaruh yang kuat ide-de dari wahdat al-wujûd ala Ibn 'Arabî. Dalam konteks ini, Nasr harus menjelaskan keabsahan dan validitas hasil berfikir imaginal simbolis ala sufi, terutama model Ibn 'Arabî ini. Baginya, benar bukan hanya bersumber pada rasio, tetapi intuisi dan gnostik. ${ }^{62}$

Bagi Nasr, melihat alam dengan mata intelek (mata hati) adalah melihat alam, bukan hanya dipahami sebagai realitas (wujud) benda kasar,

${ }^{59}$ Kecia Ali, "A Companion to Muslim Ethics", Journal of Church and State, Vol. 55, No.3, Summer , 2013, h. 563-565.

${ }^{60}$ Ali Hasan Zaidi, "Philosophy and Ideology", International Journal of Middle East Studies”, Vol. 45, 2013, h. 179-181.

61 Teofani secara literal berarti "Melihat Tuhan", tidak berarti inkarnasi Tuhan dalam sesuatu tetapi refleksi Keilahiahan dalam cermin bentuk-bentuk ciptaan. Hossein Nasr, Intelegensi, h. 201, 225.

${ }^{62}$ Ali Hasan Zaidi, "Philosophy...”, h. 179-181. tetapi sebagai teater (pertunjukan) yang pada alam dan teater itu tercermin sifat-sifat Ilahi. Alam adalah ribuan cermin yang memantulkan wajah Ilahi. Melihat alam sebagai teofani adalah melihat cerminan Tuhan dalam alam dan bentukbentuknya. ${ }^{63}$

Dalam analogi sebagai kitab, bagi Nasr, alam adalah buku "ekstensif" yang lembaranlembaran-lembarannya penuh dengan kata-kata penulisnya. Nasr memandang bahwa seni (art) dan ilmu (science) dalam Islam didasarkan pada konsep tawhîd (unity). Demikian juga dalam ilmu tentang alam semesta (cosmological sciencies) pertengahan Islam dan awal menunjukkan unitas dan adanya keterkaitan antar eksistensi. Berfikir tentang kesatuan ini mengantarkan pada keesaan Tuhan, yang mana kesatuan semesta merupakan citra-Nya. ${ }^{64}$

Pemahaman Nasr tentang alam sebagai simbol manifestasi Tuhan ini tidak bisa dilepaskan dari pemahamannya tentang konsep Islam. Menurutnya, secara universal ada tiga level makna Islam, yaitu: (1) semua makhluk berada (being) dengan kepatuhan (Muslim) "berserah kepada Tuhan", (2) semua manusia yang menerima kehendak hukum suci Tuhan sesuai fitrah adalah Muslim (taat), (3) gnostic (kearifan) adalah sifat Muslim yang tertinggi. Seluruh isi alam dihubungkan dengan keberadaan Tuhan. ${ }^{65}$ Dengan kata lain, Islam adalah kepatuhan (obeyto God) baik secara pasif (tampak pada level pertama), dan ketaatan aktif (level 2 dan 3).

Dengan gnostik ini, keberadaan bunga, burung, dan elemen kosmos lainnya dikaitkan dengan penciptanya. Semua elemen kosmos adalah pancaran Tuhan sesuai dengan level eksistensinya, baik pancaran/pantulan (reflect) yang pasif maupun aktif. Dengan pengetahuan gnostic yang holistik ini memperjelas tidak adanya pemisahan wujud secara individual.

Tidak demikian dalam pengetahuan (knowledge) dan ilmu (science) Barat sekarang. Pengetahuan dan ilmu Barat memisahkan antara curiosity (semangat

\footnotetext{
${ }^{63}$ Hossein Nasr, Intelegensi..., h. 201.

${ }^{64}$ Nasr, "Science and Civilization in Islam" dalam http:// www.fordham.edu/halsall/med/ nasr.html, diakses pada 30 April 2017.

${ }^{65}$ Nasr, "Science..., diakses pada 30 April 2017.
} 
keingintahuan) dan even. Gnostic adalah cara pandang yang menekankan (1) kesatuan bersama alam (one with nature), (2) memahami alam dari dalam alam (understands it "from the inside"), sementara science Barat memiliki karakteristik sebaliknya. ${ }^{66}$ Dengan demikian, gnostic ini dapat menjadi media untuk memahami keagungan alam semesta. Keislaman dalam arti gnostik dan keislaman (kepatuhan) alam dalam hal ini adalah saling terkait. Dengan kata lain, Nasr mengatakan bahwa krisis spiritual manusia modern berakar dari worldview Cartesian. Rasionalisme Cartesian dibangun atas dasar pemisahan antara realitas fisik dan metafisik, antara jiwa dan materi.

Terkait dengan ini, perlu adanya redefinisi tentang konsep intelek dan fungsinya, yang di Barat tidak menyentuh dan tidak mengantarkan pada pengertian gnostik tentang alam. Dipandang sebagaimana teks, alam adalah pabrik simbol (nature is a fabric of symbols), yang harus dibaca sesuai dengan makna-makna pesannya. Bagi Nasr, Alquran sendiri menyebut alam sebagai ayat (signs) yang syarat dengan makna. Dengan demikian, baik alam maupun Alquran berbicara tentang wujud Tuhan. Tugas manusia adalah memahami dan mengungkap signs sehingga kemudian darinya manifestasikan kebenaran.

Bagi ahli hukum, ayat Alquran hanya dipahami sebagai perintah atau larangan (prescription), tetapi bagi kaum gnostik memahaminya sebagai simbol. Alam adalah simbol. Nasr mengatakan bahwa spirit Islam menekankan pada unitas alam (unity of nature), di mana kesatuan tersebut menjadi tujuan dari ilmu-ilmu kealamannya.

Dalam konteks ini, Nasr jika dipandang dari kacamata Capra sebagaimana Noer termasuk kelompok cenderung menggunakan cara berfikir imaginatif (imaginative thinking). Selanjutnya, keragaman tajallî Tuhan dikonsepsikan menjadi lima hirarkhi (alhadarât al-ilâhiyat al-khamsah) yakni, (1) dunia hakikat Tuhan (lâhût), (2) dunia nama dan sifat Tuhan (Kecerdaan Universal), (3) dunia yang dipahami (dunia zat malaikat/jabarut), (4) dunia psikis dan manifestasi (malakût), (5) dunia fisik (nâsût). ${ }^{67}$

\footnotetext{
${ }^{66}$ Nasr, "Science..., diakses pada 30 April 2017.

${ }^{67}$ Nasr, Sain..., h. 74, Lihat Nasr, Knowledge and the Sacred, (New York: Crossroad Publishing Co., 1981), 129; Lihat
}

Kembali kepada tradisi, yang memadukan keduanya berdasarkan unitas. Teori rim and axis memberikan penjelasan bahwa hakikat (realitas) dunia ini terdiri dari dua aspek, (1) al-zhâhir dan 2) al-bâtin. Bentuk lahiriah benda-benda bukanlah ilusi, tetapi mereka memiliki hakikat pada levelnya. Namun, benda-benda tersebut pada dasarnya mengalami "gerak descendent" pemisahan dari "principle" yang berada di pusat, yang dapat diidentifikasi sebagai "yang batin".

Dalam konteks kehidupan manusia, bahwa hidup pada tataran "lahir" berarti mensyukuri eksistensi. Tetapi diam dan puas pada level ini berarti menghianati watak kemanusian itu sendiri yang seharusnya bergerak ascendent (bergerak naik). Dengan kata lain, manusia bergerak dari pinggir (periphery) menuju pusat, yakni transcendent, atau bergerak dari outward ke inward.$^{68}$

Pemahaman alam yang demikian, ketika merujuk pada konsep trans-substansial movementnya Mulla Shadra, kita dapat melihat kemiripan trans-substansial movement dari Nasr. Secara spesifik, Nasr menekankan gerak ascendant (naik) bukan gerak descendent (turun). Istilah yang berberda dari Nasr dengan Shadra tampak pada istilah rim and axis yang diusung Nasr dengan istilah adhan (esensi) dan a'yan (realitas sejati).

\section{Pandangan Nasr tentang Manusia}

Nasr memulai pembahasan tentang etika lingkungan dari konsep tauhid dan peran manusia. Manusia sebagaimana dalam Alquran berperan hamba ('abd) sekaligus sebagai khalifah (khalifah) Tuhan. Dua kata ini menjadi kunci pemahaman tentang manusia.

Alquran, menurut Nasr telah menjelaskan secara tegas posisi manusia sebagai khalîfah. Ini sebagaimana referensi Alquran pada Q.S. al-Baqarah [2]:30. Kualitas seorang khalîfah diukur Tuhan dengan barometer penghambaan ('ubûdiyyah) pada Tuhan. Menurut Nasr, manusia adalah hamba Tuhan ('abd Allâh), yang karenanya manusia harus menaati-Nya. ${ }^{69}$ Sebagai 'abd Allâh

\footnotetext{
Eha Juhaiha, Etika..., h. 65-66.

${ }^{68}$ Nasr, Islam and the Plight of Modern Man..., h. 45-47.

69 Zul'azmi Informasi Yaakob, Zailan Moris, "Human Rights in Dealing with the Environmental Crisis: Seyyed Hossein
} 
manusia seharusnya pasif, sementara sebagai khalîfah manusia harus aktif di dunia, yakni dengan memelihara keharmonisan alam, menyebarkan keberkahan dan karunia. Hal ini karena manusia adalah wakil atau perantara.

Dalam konteks ini, Nasr juga menegaskan bahwa manusia tidak boleh hanya menjadi khalîfah di satu sisi, juga tidak boleh hanya menjadi khalîfah saja di sisi lain. Tetapi, dua sisi ini harus melekat sehingga dia sebagai hamba yang sentiasa taat kepada Tuhan yang menciptakannya. Ini diungkapkan oleh Nasr: “...you cannot be khalifatullâh without being "abdullâh". ${ }^{\circ}$ Pandangan ini berbeda dengan pemikiran Nasruddin Anshoriy $^{71}$ di mana, dia meletakkan antara dua konsep tersebut (khalîfah dan 'abdullâh) sebagai strata. Khalîfatullâh menurut Nasruddin Anshoriy adalah derajat tertinggi di atas abdullâh.

Di antara "tugas" Tuhan adalah memelihara alam semesta. Sebagai wakil-Nya, manusia dalam pandangan Nasr juga "bertugas" sebagaimana yang diwakilinya. Dengan kata lain, dengan cara yang sama sebagaimana Tuhan memelihara alam, maka manusia juga harus mengasuh dan memelihara alam. Di sinilah manusia memainkan peran penting. ${ }^{72}$

Manusia menyandang predikat sebagai wakil Tuhan. Hal ini karena manusia bersedia menerima amanah (amânat) dari Tuhan. Manurut Nasr, manusia perusak alam sama dengan mengabaikan/ mengkhianati amanat. Atau dengan kata lain, merusak alam sama dengan merusak hubungan dengan Tuhan.73 Bagi Nasr, tidak ada yang lebih berbahaya bagi alam semesta dibandingkan dengan praktik kekuasaan wakil Tuhan yang tidak lagi menerima kenyataan dirinya sebagai hamba Tuhan yang seharusnya tunduk pada hukum-hukumNya. Tidak ada makhluk yang lebih berbahaya di muka bumi ini dibandingkan khalifah Allah yang tidak lagi sadar dirinya adalah 'abd Allâh.

Nasr's Perspective", International Journal of Islamic Thought, Vol.n2, 2012, h. 80-90.

${ }^{70}$ Seyyed Hossein Nasr, Islam and the Challenge of the 21st Century(Kuala Lumpur: Dewan Bahasa dan Pustaka, 1993), hal. 35; Lihat juga Zul'AzmilnformasiYaakob, ZailanMoris, “Human Rights..., h. 87. Lihat Eha Julaiha, Etika..., h. 49-51.

${ }^{71}$ Suwito NS, Eko-Sufisme..., h. 97-99.

${ }^{72}$ Nasr, "Krisis"..., h. 9.

${ }_{73}$ Nasr, "Krisis"... , h. 9.
Sufisme menyediakan sarana perjalanan manusia tersebut. Hal ini karena ada dua ajaran dasar sufisme menurut Nasr, yakni (1) kesatuan transenden wujud, (2) manusia sempurna. Prinsip pertama, sebagaimana Ibn 'Arabî bahwa segala realitas adalah cermin Tuhan sebagai tajallî nama dan sifat-Nya. Manusia adalah satu-satunya makhluk yang dapat menjadi cermin lengkap Tuhan. ${ }^{74}$

Konsep kepatuhan manusia yang dikonsepsikan Nasr ada kesamaan dengan paradigma al-Ghazali tentang peran manusia. Istilah khaliffah yang digunakan al-Ghazali sama dengan istilah pada Nasr. Hanya saja Nasr juga menyebut peran khalîfah pada diri manusia ini sebagai cermin Tuhan yang utuh ada insân kâmil (par excellence) atau dalam istilah Ghazali disebut dengan al-wâsilûn atau al-mutâ yang didefinisikan sebagai khaliffah Allah, yakni pengganti, pengatur yang memiliki posisi paling tinggi di alam semesta. 75

Konsepsi tentang manusia yang berkaitan dengan kepatuhan sebagai hamba ('abd) Tuhan yang secara pasif harus menerima dan taat kepada hukum-hukum Allah dan peran manusia sebagai khalîfah yang harus aktif melakukan kegiatan ascendent inilah etika lingkungan yang dibangun oleh Nasr. Dengan konsepsi ini, Nasr tidak terjebak pada antroposentrisme sebagaimana Clare A. Gunn, Paul Shephard dan Daniel McKinley, tidak pula kelompok ekosentris Baird Callicott dan kawan-kawan dan ecofeminisme seperti Maria Mies, Vandana Shiva, Mery Melor, dan Ariel Salleh.

Nasr memiliki corak etika lingkungan sendiri yang dapat disebut dengan teori eco-sufisme. Teori ini secara geneologis bermuara pada wahdat al-wujûd Ibnû `Arabî, sekalipun paradigmanya berpangkal dari realitas kosmos. Jika dikontraskan dengan dengan teori-teori etika lingkungan modern, maka posisi pemikiran Nasr sebagaimana berikut: ${ }^{6}$

${ }^{74}$ Lihat Nasr, Islamic Life and Thought, (London: George Allen Unwin, 1981), 193; Lihat juga Nasr, Tasawuf Dulu dan Sekarang, h. 18.

75 Annimarie Schimmel, Dimensi Mistik dalam Islam, (Jakarta: Pustaka Firdaus, 2000), h. 282-283.

76 Nasr, Islamic, 193-199; Nasr, Tasawud Dulu dan Sekarang..., h. 18-24. 


\begin{tabular}{|c|c|c|c|c|}
\hline Tinjauan & $\begin{array}{l}\text { Ekologi } \\
\text { Dangkal }\end{array}$ & $\begin{array}{l}\text { Ekologi } \\
\text { Dalam }\end{array}$ & $\begin{array}{l}\text { Sosial } \\
\text { Ecologi }\end{array}$ & $\begin{array}{l}\text { Etika } \\
\text { Ekologi } \\
\text { Nasr }\end{array}$ \\
\hline $\begin{array}{l}\text { Pandangan } \\
\text { dunia }\end{array}$ & antroposentris & Ecosentris & $\begin{array}{l}\text { Naturalisme } \\
\text { dialektis }\end{array}$ & Realisme \\
\hline $\begin{array}{l}\text { Posisi } \\
\text { krisis }\end{array}$ & $\begin{array}{l}\text { Problem } \\
\text { teknis }\end{array}$ & Problem nilai & $\begin{array}{l}\text { Problem } \\
\text { Sosial }\end{array}$ & $\begin{array}{l}\text { Problem } \\
\text { Eksistensial }\end{array}$ \\
\hline $\begin{array}{l}\text { Evolusi } \\
\text { kosmos }\end{array}$ & Darwinisme & Konservatisme & $\begin{array}{l}\text { Evolusi } \\
\text { social }\end{array}$ & $\begin{array}{l}\text { Gerak, } \\
\text { Trans } \\
\text { Substansial }\end{array}$ \\
\hline $\begin{array}{l}\text { Sumber } \\
\text { utama } \\
\text { ilmu }\end{array}$ & $\begin{array}{l}\text { Nalar } \\
\text { instrumen } \\
\text { Saintisme }\end{array}$ & $\begin{array}{l}\text { Intuisi } \\
\text { Mistisisme }\end{array}$ & $\begin{array}{l}\text { Nalar } \\
\text { dialektis }\end{array}$ & $\begin{array}{l}\text { Nalar } \\
\text { diskursif- } \\
\text { intuitif } \\
\text { Filsafat- } \\
\text { intiutif }\end{array}$ \\
\hline Afinitas & Saintisme & Mistisisme & $\begin{array}{l}\text { Dialektika } \\
\text { Hegel }\end{array}$ & $\begin{array}{l}\text { Filsafat } \\
\text { Hikmah }\end{array}$ \\
\hline $\begin{array}{l}\text { Fokus } \\
\text { perubahan }\end{array}$ & Structural & Cultural & Structural & $\begin{array}{l}\text { Sistemik } \\
\text { (cultural- } \\
\text { struktural) }\end{array}$ \\
\hline $\begin{array}{l}\text { Fokus } \\
\text { relasi }\end{array}$ & Dominasi & Interspesies & Interspesies & $\begin{array}{l}\text { Gradasi } \\
\text { eksistensial }\end{array}$ \\
\hline Nilai & Kemajuan & Kedamaian & Persamaan & Keadilan \\
\hline
\end{tabular}

Demikian juga, jika paradigma Nasr disandingkan dengan para Cartesian Barat dapat dilihat sebagai berikut: ${ }^{77}$

\begin{tabular}{ll}
\hline Modern-Cartesian & Tradisional Nasrian \\
\hline $\begin{array}{l}\text { Prinsip utama: mathematization } \\
\text { of nature }\end{array}$ & $\begin{array}{l}\text { Prinsip utama: resacralization of } \\
\text { nature }\end{array}$ \\
\hline $\begin{array}{l}\text { Kosmos adalah mesin raksasa } \\
\text { yang mekanis }\end{array}$ & $\begin{array}{l}\text { Kosmos adalah selubung } \\
\text { (teophani) kehadiran Tuhan }\end{array}$ \\
\hline $\begin{array}{l}\text { Alam adalah mati, substansi } \\
\text { tanpa makna }\end{array}$ & $\begin{array}{l}\text { Alam adalah hidup, syarat pesan } \\
\text { spiritual }\end{array}$ \\
\hline $\begin{array}{l}\text { Alam diketahui dari sisi luar yang } \\
\text { terpisah dari manusia sebagai } \\
\text { pengamat }\end{array}$ & $\begin{array}{l}\text { Alam disingkap dalam hubungan } \\
\text { eksistensial manusia }\end{array}$ \\
\hline $\begin{array}{l}\text { Tujuan sain: kontrol empiris atas } \\
\text { alam }\end{array}$ & $\begin{array}{l}\text { Tujuan sain: mengenal alam } \\
\text { secara holistik }\end{array}$ \\
\hline $\begin{array}{l}\text { Keseluruhan tidak lebih dari } \\
\text { bagian-bagian }\end{array}$ & $\begin{array}{l}\text { Keseluruhan memiliki sifat-sifat } \\
\text { yang tidak dimiliki oleh bagian- } \\
\text { bagian }\end{array}$ \\
\hline $\begin{array}{l}\text { Sistem-sistem hidup direduksi } \\
\text { menjadi bagian-bagian materi } \\
\text { anorganik }\end{array}$ & $\begin{array}{l}\text { Sistem hidup tidak dapat } \\
\text { direduksi komponen- } \\
\text { komponennya }\end{array}$ \\
\hline $\begin{array}{l}\text { Pikiran terpisah dari tubuh, subjek } \\
\text { terpisah dari objek }\end{array}$ & $\begin{array}{l}\text { Pikiran-tubuh, subjek-objek adalah } \\
\text { dua level eksistensi }\end{array}$ \\
\hline $\begin{array}{l}\text { Logika: either ... or..., linier, } \\
\text { dikotomis }\end{array}$ & $\begin{array}{l}\text { Logika: both... and, non linier, } \\
\text { komplek }\end{array}$ \\
\hline $\begin{array}{l}\text { Tidak ada hubunga antara fakta } \\
\text { dan nilai }\end{array}$ & $\begin{array}{l}\text { Fakta dan nilai tidak bisa } \\
\text { dipisahkan }\end{array}$ \\
\hline $\begin{array}{l}\text { Rasio instrumental yang tunduk } \\
\text { empiri }\end{array}$ & \begin{tabular}{l} 
Rasio yang merujuk pada Intelek \\
\hline
\end{tabular} \\
\hline
\end{tabular}

Pada bagian ini akan dibahas berkaitan kesalahan paradigma Barat melihat alam menurut Nasr. Bagi Nasr sebagaimana telah disebut di muka,

77 Nasr, Islamic...,h. 193-199; Nasr, Tasawud Dulu dan Sekarang..., h. 18-24. sebab utama krisis lingkungan adalah karena krisis spiritual. ${ }^{78}$ Lebih lanjut, Nasr mengatakan bahwa krisis spiritual di berbagai belahan dunia, terutama di Barat dipicu dari pola Cartesian yang lebih menekankan rational thinking. Dalam konteks ini, menurut Capra sebagaimana dikemukakan oleh Noer ${ }^{79}$ yang mengatakan bahwa ada dua macam cara berfikir, (1) berpikir rasional (rational thinking) dan (2) berpikir imaginal (imaginal thinking). Ciri cara berpikir rasional adalah (a) diskursif, (b) bertumpu pada penggunaan rasio, (c) menekankan kemajemukan, diversitas, perbedaan, dan keterpisahan (either... or...). Sementera itu, berpikir imaginal, yang sering juga disebut berpikir intuitif, menekankan penggunaan hati. Ciri berpikir imaginal di antaranya adalah (a) cenderung menekankan keesaan, keidentikan, dan pemaduan, (b) cara berpikir "baik ini maupun itu," (both... and...) atau "kedua-duanya." Cara berikir ini menggunakan prinsip coincidentia oppositorum atau prinsip hubungan yin-yang. Cara berpikir ini dalam sejarah Islam digunakan oleh para sufi, filosof yang sufi atau filosof lluminasionis (Isyrâqî).

\section{Penutup}

Konsep etika lingkungan (ecological ethics) Nasr diturunkan dari konsep unitas (tawhîd), yakni tawhîd wahhdat al-wujûd). Baginya, keberadaan alam (kosmos) dan segala macam ini adalah teophani Tuhan. Tuhan dapat dikenali melalui ciptaan-Nya. Dengan pemahaman seperti ini, maka pada dasarnya etika lingkungan yang dibangun oleh Nasr memiliki basis tasawuf Ibn 'Arabî, walaupun kemudian dikembangkan lebih sistematis.

Nasr memandang sebagaimana pendahulunya, bahwa hubungan antara alam yang beraneka ragam dengan Tuhan ibarat satu wajah dengan seribu cermin. Allah adalah tunggal, hanya saja pantulannya yang banyak, maka semesta "memuat" aspek Tuhan. Tuhan hanya dapat memantul dengan kualitas "penuh" pada manusia sebagai khalîfah di bumi. Tugas khalîfah adalah

\footnotetext{
${ }^{78}$ Nasr, "Islam dan Krisis Lingkungan”, terj. Dalam Islamika. No. 3 Januari-Maret 1994, h. 5.

79 Noer, "Mencari Keselarasan Sain Modern dan Sufisme", dalam www.icc-jakarta.com/Sain Modern dan Sufisme Sain Modern dan Sufisme
} 
melestarikan semesta yang menjadi "wadag" Tuhan. Belajar melalui alam, sama dengan belajar langsung dengan pencipta-Nya.

Nasr kemudian mengembangkan konsep tawhîd wahdat al-wujûd menjadi teori rim and axis. Pada teori ini, terdapat unsur kemiripan dan kesamaan dengan konsep a'yân Mulla Sadra. Berkaitan dengan peran manusia sebagai pemakmur alam sama dengan sufi-sufi lain seperi al-Ghazâli, dan al-Jîî. Sufi menyediakan jalan yang digunakan untuk menemukan kesadaran tertinggi manusia dan trans-substansial movement. Manusia yang dapat menggunakan maha hati (intelek) adalah khalîfah dan sekaligus 'abd Allâh. Mereka inilah yang dapat memahami alam sebagai teofani Tuhan. Dengan demikian, merusak alam sama dengan “merusak' Tuhan. Dalam konteks etika lingkungan modern, Nasr dapat digolongkan dalam kelompok eco-spirituality atau green spirituality, atau tepatnya dalam kelompok eco-sufisme, yang kontras berbeda dengan antroposentrism maupun eco-centrism.

\section{Pustaka Acuan}

Ali, Kecia, "A Companion to Muslim Ethics", Journal of Church and State, Vol..55, No.3, Summer, 2013.

Asadi, Siavash, "An Interpretation of Proper Name References Based on "Principality of Existence" Theory", International Journal of Islamic Thought, Vol.11,Jun 2017.

Chittick, William C, "Preface", dalam Mehdi Aminravazi and Zailan Moris, The Complete Bibliography of Seyyed Hossein Nasr from 1958-1993. Kuala Lumpur: TP, 1994.

Clemens,Will, "On the Big Bang Theory Success: A Casual Analysis", Pennsylvania Literary Journal,Cochran, Vol. 5, No. 3, 2013.

Cowdin, Daniel, "Environmental Ethics" dalam Theological Studies, 2008.

Crites, "A New Movement Finds Commonality in Religious Tenets and Environment Causes", dalam http://www.edu/malamalama/2007/09/ f1-ecology.htm, diakses pada 7 Juni 2017.

Crowther,Kathleen, et. al, "The Book Everybody Read: Vernacular Translations of Sacrobosco's Sphere in the Sixteenth Century", Journal for the History of Astronomy, Vol. 46, No. 1, 2015.
Dagli, Caner, "On Beginning a New System of Islamic Philosophy", The Muslim World, Vol. 47, No. 1, Jan 2004.

Dien, M. Izz, "Islam and Environment: Theory and Practies", dalam R. C. Foltz (Ed.), Environmentalism, NY: Novan Science Publishers, 2013.

Encyclopædia Britannica Online, http://www. britannica.com /EBchecked/ topic/485405/ Qajar-dynasty, 29 Apr. 2009.

Evanoff, Richard, "Reconciling Self, Society, and Nature in Environmental Ethics". Capitalism, Nature, Socialism (16), 3, 2005.

Ghazâlî, al-, Abû Hâmid, Misykat al-Anwâr, dalam Muhammad Mustafâ Abû A'lâ (Ed.), Al-Qusûr al-Awâly, Kairo: Maktabah Jundi, 1970. , Makh al-Nazar fî al-Mantiq, Beyrût: Dâr al-Nahdlah al-Hadisah, 1996.

, Ihyâ‘Ulûm al-Dîn, Beirut: Dâr al-Fikr, Juz I, TT.

Gill, Farhat Iftikhar, "Sufism and Modernity", Journal of Asian Civilizations, Vol. 36, No. 2, 2013.

Goldsborough, Reid, "How Important is Information", Tech Directions; Ann Arbor, Vol. 72, No. 4, Nov, 12, 2012.

Gottlieb, Roger, A Greener Faith: Religious Environmentalism and Our Planet's Future. New York: Oxford, 2006.

Hagen, Kirk D, “Eternal Progression in Multiverse: An Explorative Mormon Cosmology", Dialogue: A Journal of Mormon Thought, Vol. 39, No.2, 2006.

Hamed, "Egypt", dalam R. C. Foltz (Ed.), Environmentalism in the Muslim World. NY: Novan Science Publishers, 2005.

Hamid, Abdul, Konsep Tradisi Menurut Seyyed Hossein Nasr (Tesis). Jakarta: UIN Jakarta, 2002.

Hollenbach, The Common Good and Christian Ethics. New York: Cambridge, 2002.

Hope and James Young, "Islam and Ecology", dalam http://www.crosscurrents.org/ islamecology.htm, didownload pada 7 Juni 2008.

Hope and Young, "Islam", dalam http://www. crosscurrents.org/ islamecology, didownload tanggal 7 Juni 2008.

Ibn 'Arabî, Muhy al-Dîn, Kitâb al-Jalâlah dalam Rasâ'il Ibn al-'Arabî, Part 2. HeydarabadDeccan: The Dairat al-Ma'ârif al-Osmania, 1948. 
, al-Futuhât al-Makkiyyah, 4 Jilid. Kairo: Dâr al-Kutub al-'Arâbiyyah al-Kubrâ, 1329/1911. Dicetak ulang di Beyrût: Dâr al-Fikr, TT, Jilid 2, 1991.

Julaiha, Eha, Etika Lingkungan: Prespektif Tasawuf Nasr (Tesis). Jakarta: PPs IAIN Syarif Hidayatullah, 2001.

Kinsley, David, Ecology and Religion: Ecological Spirituality in Cross-Cultural Prespective. Prentice-Hall, 1995.

Konchak, William and Pascual Unai, "Converging Paradigm fo a Co-evalutionary Enveronmrntal Limit Discourse", dalam Environmental Economy and Policy Research. Discussion Paper Series University of Cambridge, Number 14, 2005.

Louchakova-Schwartz, Olga, “A Phenomenological Approach to Illuminationist Philosophy: Suhrawardi's Nur Mujarrad And Husserl's Reduction", Philosophy East and West, Vol. 65. No.4, Oct 2015.

Mellor, Mery, Feminism and Ecology. Cambrigde: Polity, 1997.

Mies, Maria and Shiva, Vandana, Ecofeminism. London: Zed Books, 1993.

Nasr, Seyyed Hoosein, "Islam dan Krisis Lingkungan" terj. Dalam Islamika.No.3 Januari-Maret 1994.

, "Science and Civilization in Islam" dalam http://www.fordham.edu/halsall/med/ nasr. html, diakses pada 30 April 2009.

Islam and the Challenge of the 21st Century. Kuala Lumpur: Dewan Bahasa dan Pustaka, 1993. , Man and Nature: The Spiritual Crisis of Modern Man. London: George Allen and Unwin, 1978.

, Islam dalam Cita dan Fakta. Terj. Abdul Rahman Wahid dan Hasyim Wachid. Jakarta: LAPENNAS, 1981.

, Islamic Life and Thought. London: George Allen Unwin, 1981.

, "Islam and the Environmental Crisis", dalam The Islamic Quaterly. Vol. XXXIV. No.

4, 1994.

, “Islam dan Krisis Lingkungan” terj. Dalam Islamika.No.3 Januari-Maret 1994.

, Intelegensi \& Spiritualitas Agama-agama.

Terj. Suharsono dkk. Jogjakarta: Inisiasi Press, 2004 .
, Intelektual Islam: Teologi, Filsafat, dan Gnosis. Terj. Suharsono dan Djamaluddin MZ. Yogyakarta: CIIS Press, 1995.

, Knowledge and the Sacred. New York: Crossroad Publishing Co, 1981.

Noer, Kautsar Azhari, Ibn al 'Arabî, Wahdat al-Wujûd dalam Perdebatan. Jakarta: Paramadina, 1995. , “Menyemarakkan Dialog Agama”, dalam Dekonstruksi Mazhab Ciputat. Bandung: Aman Wacana Mulia, 1999.

, "Mencari Keselarasan Sain Modern dan Sufisme", dalam www.icc-jakarta.com/Sain Modern dan Sufisme Sain Modern dan Sufisme, didownload, 24 Juni 2009.

Nurjaya, "Kearifan Lokal dan Pengelolaan SDA", dalam http://www.manifesmaya. blogspot. com /2008/kearifan-lokal-dan-pengelaan.html, didownload pada 7 Juni 2008.

Partidge, Ernest, “Topic Environmental Ethics". www.gofly.org, 2008.

Riahi, Ali Arshad,Mohammad Nassrisfahani, Mehdi Jafarzadeh, "Mulla Sadra and Evolution Theory", International Journal of Islamic Thought, Vol. 8, Dec 2015.

Rice, Gillian, "Pro-environmental Behavior in Egypt: Is there a Role for Islamic Environmental Ethics?" dalam Journal of Business Ethics, 65, 2006.

Salleh, Ariel, "Ecofeminism as Sociology". CSN (14), 1, 1993.

Sanionis, Athur, "Enchanted Landscape: Senuous Awareness as Mystical Practice among Sufis in North India", dalam The Australian Journal of Anthropology (19), 2008.

Schimmel, Annimarie, Dimensi Mistik dalam Islam. Jakarta: Pustaka Firdaus, 2000.

Kartanegara, Mulyadhi, Gerbang Kearifan. Jakarta: Lentera Hati, 2005.

Shephard, Paul, "Ecology and Man - A Viewpoint", dalam Paul Shephard and Daniel McKinley (Ed.), The Subversive Science: Essays Toward an Ecology of Man. Boston: Huougton-Mifflin, 1969.

Smith, Jane I, "Seyyed Hossein Nasr", dalam John L. Esposito, The Oxford Encyclopedia of the Modern Islamic Word. New York-Oxford: Oxford University Press, 1995.

Sponsel, Lieslie, "Why a Tree is more than a Tree: Reflection on the Spiritual Ecology of Sacred 
Tree in Thailand", dalam Sulak Sivaraksa, et. al. (Ed.), Santi Pracha Dhamma. Bangkok: Santi Pracha Dhamma Institute, 2001.

Sudarsono, Bumiku Semakin Panas. Jogjakarta: PPLHRJ, 2008.

Tim Penyusun, Ensiklopedi Islam, Jakarta: PT Ichtiar Baru Van Hoev, Cet. ke- 4, Vol. 2, 1999.

Tucker, Mary Evelyn and Grim, John A, "Introduction: The Emerging Alliance World Religions and Ecology", Daedalus. (130), 4. Fall, 2001.

Walker,Bethany J, "Commemorating the Sacred Spaces of the Past: The Mamluks and the Umayyad Mosque at Damascus", Near Eastern Archaeology; Vol. 67, No. 1, 2009.
White, Lynn, "The Historical Roots of Our Ecological Crisis", Science. No. 155, 1967.

Yaakob, Zul'Azmilnformasi; Moris, Zailan, “Human Rights in Dealing with the Environmental Crisis: Seyyed Hossein Nasr's Perspective", International Journal of Islamic Thought, Vol. 2, 2012.

Yonck,Richard, "Making Waves in The Cosmos", The Futurist; Washington, Vol. 48, No, 4, Jul/Aug, 2014.

Zaidi, Ali Hasan, "Philosophy and Ideology", International Journal of Middle East Studies", Vol. 45, 2013. 